\title{
PENINGKATAN EKSISTENSI PENDIDIKAN DI MTS. BABUL MUJAHIDIN MELALUI PELATIHAN OUTDOOR CLASS
}

\author{
Heri Rahmat \\ Institut Agama Islam Negeri Mataram \\ E-mail: heryhemat77@gmail.com
}

\begin{abstract}
Abstrak: Kurikulum 2013 mengamanatkan esensi pendekatan ilmiah dalam pembelajaran. Metode ilmiah merujuk pada teknik-teknik investigasi atas fenomena atau gejala, memperoleh pengetahuan baru, atau mengoreksi dan memadukan pengetahuan sebelumnya Outdoor learning memberikan dorongan perasaan kebebasan bagi siswa. Sebagai hasil dari tidak dibatasinya ruang berpikir siswa oleh dinding-dinding kelas. Berdasarkan uraian di atas maka Kegiatan Pengabdian kepada Masyarat ini ditujukan sebagai menjembati akademisi kampus IAIN Mataram dengan lembaga pendidikan islam sebagai basis utamanya. Sedangkan fokus utama dari Kegiatan Pengabdian kepada Masyarat ini adalah sebagai langkah inisiasi untuk meningkatkan eksistensi pendidikan yang berlangsung di MTs. Babul Mujahidin agar masyarakat sekitar, khususnya di Desa Bayan, lebih mengenal keberadaan MTs. Babul Mujahidin. Selanjutnya berdasarkan analisis kondisi madrasah tersebut. Hasil kegiatan ini adalah peserta pelatihan dapat memahami bagaimana penerapan pendekatan pembelajaran di luar kelas serta dapat menerapkan pendekatan pembelajaran di luar kelas, hal ini tercermin dari perangkat pembelajaran yang sudah dikembangkan oleh guru..
\end{abstract}

Kata Kunci: Pelatihan, Pengembangan, Website

\section{PENDAHULUAN}

Kurikulum 2013 mengamanatkan esensi pendekatan ilmiah dalam pembelajaran. Metode ilmiah merujuk pada teknik-teknik investigasi atas fenomena atau gejala, memperoleh pengetahuan baru, atau mengoreksi dan memadukan pengetahuan sebelumnya. Salah satu pelajaran yang menggunakan pendekatan ilmiah dalam kurikulum 2013 yaitu pelajaran IPA terpadu, dimana siswa diarahkan untuk mencari dan menemukan sendiri sehingga dapat membantu untuk memperoleh pemahaman yang lebih mendalam tentang alam sekitar.

Dalam pembelajaran IPA terpadu memungkinkan peserta didik secara individual maupun kelompok aktif mencari, menggali, dan menemukan konsep serta prinsip secara menyeluruh dan nyata. (Depdikbud, 1996). Peserta didik dapat memperoleh pengalaman langsung sehingga dapat menambah kekuatan untuk menerima, menyimpan, dan menerapkan konsep yang telah dipelajarinya. 
Dengan demikian, peserta didik terlatih untuk dapat menemukan sendiri berbagai konsep yang dipelajari secara menyeluruh, bermakna, otentik, dan aktif.

Salah satu metode pembelajaran yang dapat memotivasi siswa dalam belajar khususnya pada materi zat aditif makanan adalah dengan diterapkannya metode belajar outdoor learning. Berdasarkan hasil observasi, SMP 8 Pontianak memiliki halaman dan lapangan yang luas. Halaman tersebut dapat digunakan sebagai sarana tempat siswa belajar karena di sekitar halaman terdapat dua buah pohon yang membuat halaman menjadi teduh. Penggunaan metode outdoor dalam pembelajaran bisa menjadi suatu alternatif bagi guru dalam mengajar. Karena proses pembelajaran pada dasarnya tidak hanya bisa dilakukan di dalam ruang kelas, tapi dapat juga belajar di ruang terbuka seperti di taman lingkungan sekolah agar suasana menjadi lebih segar yang dapat menambah semangat dan motivasi siswa untuk belajar

Outdoor learning memberikan dorongan perasaan kebebasan bagi siswa. Sebagai hasil dari tidak dibatasinya ruang berpikir siswa oleh dinding-dinding kelas. mengungkapkan bahwa outdoor learning adalah metode pembelajaran sains dengan melakukan petualangan di lingkungan sekitar dengan disertai pengamatan secara teliti yang hasilnya dicatat ke dalam lembar kerja pengamatan. ${ }^{73}$ Hal tersebut mengakibatkan pembelajaran lebih bermakna dan juga mengakibatkan siswa lebih termotivasi untuk mempelajari Materi. Program pembelajaran outdoor memberikan kesempatan kepada siswa secara aktif untuk terlibat dalam seluruh kegiatan yang dilakukan. Dengan langsung terlibat pada aktivitas, siswa akan segera mendapat umpan balik tentang dampak dari kegiatan yang dilakukan. Suyadi (dalam Husamah,) mengungkapkan bahwa kelebihan dari metode outdoor learning dapat membuat pikiran menjadi lebih jernih, pembelajaran terasa lebih menyenangkan, variatif, rekreatif, lebih rill, dan kerja otak menjadi lebih rileks. ${ }^{74}$

MTs Babul Mujahidin adalah salah satu lembaga pendidikan menengah yang ada di Desa Bayan. MTs Babul Mujahidin berlokasi di Jln. Pemuda Canada/Bayan Timur tepatnya di belakang Kantor Desa Bayan. Selain itu gedung MTs Babul Mujahidin terletak di antara pemukiman warga Desa Bayan. Oleh

${ }^{73}$ Husamah, Pembelajaran Luar Kelas Outdoor Learning, (Jakarta: PrestasiPustakaraya, 2013), h. 19.

${ }^{74}$ Ibid., h. 25. 
karena itu posisi MTs Babul Mujahidin dapat dikatakan cukup strategis karena dapat dengan mudah dijangkau oleh masyarakat.

Meskipun demikian keberadaan MTs Babul Mujahidin masih dianggap sebelah mata oleh masyarakat sekitar. Hal ini ditunjukkan dengan rendahnya partisipasi masyarakat sekitar Desa Bayan untuk memasukkan anak-anak mereka di MTs Babul Mujahidin. Masyarakat sekitar Desa Bayan cenderung memasukkan anak-anak mereka setelah lulus dari pendidikan dasar (SD/MI) untuk melanjutkan di sekolah tingkat menengah (SMP/MTs) yang lain yang berada di Desa lain dengan hingga $5 \mathrm{~km}$ dari Desa Bayan.

Berdasarkan uraian di atas maka Kegiatan Pengabdian kepada Masyarat ini ditujukan sebagai menjembati akademisi kampus IAIN Mataram dengan lembaga pendidikan islam sebagai basis utamanya. Sedangkan fokus utama dari Kegiatan Pengabdian kepada Masyarat ini adalah sebagai langkah inisiasi untuk meningkatkan eksistensi pendidikan yang berlangsung di MTs. Babul Mujahidin agar masyarakat sekitar, khususnya di Desa Bayan, lebih mengenal keberadaan MTs. Babul Mujahidin.

\section{PEMBAHASAN}

\section{Pembelajaran di luar Kelas}

Pendekatan pembelajaran di luar kelas (outdoor study) adalah sebuah pendekatan pembelajaran yang menggunakan suasana di luar kelas sebagai situasi pembelajaran berbagai permainan sebagai mendia transformasi konsep-konsep yang disampaikan dalam pembelajaran. Pendekatan pembelajaran di luar kelas menggunakan beberapa metode seperti penugasan, tanya jawab, dan belajar sambil melakukan atau mempraktekkan dengan situasi belajar sambil bermain. Pendekatan pembelajaran diluar kelas ini memiliki kelebihan yang mendukung pada pembelajaran siswa, di antaranya sebagai berikut:

1. Mendorong motivasi belajar siswa, karena menggunakan setting alam terbuka sebagai sarana kelas, untuk memberikan dukungan proses pembelajaran secara menyeluruh yang dapat menambah aspek kegembiraan dan kesenangan

2. Guru mampu menciptakan suasana pembelajaran yang menyenangkan karena dapat berekspolarasi menciptakan suasana belajar seperti bermain 
3. Pada pembelajaran di luar kelas siswa menggunakan media pembelajaran yang kongkrit dan memahami lingkungan yang ada disekitarnya. Pada saat pembelajaran digunakan media yang sesuai dengan situasi kenyataannya, yakni berbagai permainan anak seperti seluncuran, ayunan, jungkat-jungkit dan lain-lain

4. Mengasah aktivitas fisik dan kreativitas siswa karena menggunakan strategi belajar sambil melakukan atau mempraktekan sesuai dengan penugasan. Selain memiliki kelebihan, pendekatan di luar kelas sebagai pendekatan pembelajaran juga memiliki kelemahan: memerlukan perhatian yang ekstra dari guru pada saat pembelajaran karena menggunakan media yang sesuai dengan kenyataannya di arena bermain anak yang dapat memungkinkan anak keterusan bermain di tempat tersebut.

Pembelajaran di luar kelas (outdoor study) merupakan pembelajaran yang dilakukan di luar ruang kelas atau di luar gedung sekolah, atau berada di alam bebas, seperti: bermain di lingkungan sekitar sekolah, di taman, atau di perkampungan masyarakat sekitar sehingga diperoleh pengetahuan dan nilai-nilai yang berkaitan dengan aktivitas hasil belajar terhadap materi yang disampaikan di luar kelas. Pendekatan pembelajaran di luar kelas (Outdoor study) adalah pendekatan yang dilakukan guru, dimana guru mengajak siswa belajar di luar kelas untuk melihat peristiwa langsung di lapangan yang di gunakan sebagai sumber belajar. Peran guru disini adalah sebagai motivator, artinya guru sebagai pemandu agar siswa belajar melalui pengalaman yang mereka peroleh.

Pembelajaran di luar kelas (outdoor study) ini adalah sebagai pendekatan pembelajaran dalam meningkatkan pemahaman lawan kata pada siswa. Karena dengan pembelajaran di luar kelas (outdoor study) siswa dapat merasakan pengalaman langsung melalui pengalaman sendiri di luar kelas terhadap suatu objek di lingkungan untuk meningkatkan pemahaman anak tersebut.

Melalui sudut pandang kependidikan, aktivitas pendidikan yang dilakukan di luar lingkungan sekolah, setidaknya memuat tiga konsep utama, yaitu konsep proses belajar, aktivitas luar kelas dan lingkungan. Konsep proses belajar melalui aktivitas luar kelas (outdoor study) adalah proses belajar interdisipliner melalui satu seri aktivitas yang dirancang untuk dilakukan di luar kelas. 
Pendekatan ini secara sadar mengeksploitir potensi latar alamiah untuk memberi kontribusi terhadap perkembangan fisik dan mental. Dengan meningkatkan kesadaran terhadap hubungan timbal balik dengan lingkungan, program dapat mengubah sikap dan perilaku terhadap lingkungan yang mereka peroleh melalui pengalaman langsung di luar kelas.

Kedua yaitu konsep aktivitas luar kelas merupakan suatu pendekatan dengan menggunakan kehidupan di luar ruangan yang memberikan banyak kesempatan bagi siswa untuk memperoleh dan menguasai berbagai bentuk keterampilan dasar, sikap dan apresiasi terhadap berbagai hal yang terdapat di luar kelas. Bentuk-bentuk kegiatan luar kelas dapat berupa: menjelajah atau mengamati lingkungan sekitar sekolah, mempelajari sesuatu yang mereka peroleh melalui benda-benda yang ada di sekitar lingkungan dimana kita tinggal dan lain sebagainya. Konsep lingkungan yang merujuk pada eksplorasi ekologi sebagai andalan mahluk hidup yang saling tergantung antara yang satu dengan yang lain. Pentingnya lingkungan tidak hanya dijadikan sebagai tempat belajar melainkan lingkungan juga dapat dijadikan sebagai sumber belajar yang mereka peroleh dari lingkungan tersebut, melalui pengalaman langsung di luar kelas proses pembelajaran tidak hanya di lakukan di dalam kelas melainkan lingkungan di luar kelas yang dapat lebih meningkatkan hasil belajar siswa pada suatu materi pembelajaran.

Pendekatan pembelajaran dapat di artikan sebagai titik tolak atau sudut pandang kita terhadap proses pembelajaran, yang merajuk pada pandangan tentang terjadinya suatu proses yang sifatnya masih sangat umum, di dalamnya mewadahi, menginspirasi, menguatkan dan melatari metode pembelajaran dengan cakupan teoritis tertentu. Dilihat dari pendekatannya, pembelajaran terdapat dua jenis pendekatan yaitu: (1) pendekatan yang berorientasi atau berpusat pada siswa (student centered approach) dan (2) pendekatan pembelajaran yang berorientasi atau berpusat pada guru (teacher centered approach). Kemp mengemukakan bahwa strategi pembelajaran adalah suatu kegiatan pembelajaran yang harus dikerjakan guru dan siswa agar tujuan pembelajaran dapat dicapai secara efektif dan efisien. ${ }^{75}$ Selanjutnya, dalam strategi pembelajaran terkandung

${ }^{75}$ Adelia vera, Metode Mengajar Anak di Luar Kelas (Outdoor Study), (Yogyakarta: DIVA Press, 2012), h.43. 
makna perencanaan. Artinya, bahwa strategi pada dasarnya masih bersifat konseptual tentang keputusan-keputusan yang akan di ambil dalam suatu pelaksanaan pembelajaran. Dilihat dari strateginya, pembelajaran dapat dikelompokkan ke dalam dua bagian pula, yaitu: (1) exposition-discovery learning dan (2) group individual learning. Ditinjau dari cara penyajian dan cara pengolahannya, strategi pembelajaran dapat dibedakan antara strategi pembelajaran induktif dan strategi pembelajaran deduktif.

Strategi pembelajaran sifatnya masih konseptual dan untuk mengimplementasikannya digunakan berbagai metode pembelajaran tertentu. Dengan kata lain, strategi merupakan "a plan of operation achieving something" sedangkan metode adalah "a way in achieving something". Jadi, metode pembelajaran dapat diartikan sebagai cara yang digunakan untuk menginplementasikan rencana yang sudah disusun dalam bentuk kegiatan nyata dan praktis untuk mencapai tujuan pembelajaran. Terdapat beberapa metode pembelajaran yang dapat digunakan untuk mengimplementasikan strategi pembelajaran, diantaranya: (1) ceramah; (2) demonstrasi; (3) diskusi; (4) simulasi; (5) laboratorium; (6) pengalaman lapangan; (7) brainstorming; (8) debat, (9) simposium, dan sebagainya. Berdasarkan paparan tersebut dapat disimpulkan bahwa pendekatan pembelajaran merupakan titik tolak dari sebuah pembentukan model pembelajaran yang terdiri dari startegi, metode dan teknik pembelajaran.

Tujuan pendidikan yang secara umum ingin dicapai melalui aktivitas di luar ruang kelas atau di luar lingkungan sekolah adalah:

1. Membuat setiap individu memiliki kesempatan unik untuk mengembangkan kreativitas dan inisiatif personal

2. Menyediakan latar (setting) yang berarti bagi pembentukan sikap

3. Mengembangkan kesadaran, apresiasi dan pemahaman terhadap lingkungan alam dan bagaimana manusia memiliki relasi dengan hal tersebut

4. Membantu mewujudkan potensi setiap individu agar jiwa, raga dan spiritnya dapat berkembang optimal

5. Memberikan 'konteks' dalam proses pengenalan berkehidupan sosial dengan memberikan kesempatan bagi anak-anak untuk merasakan secara langsung 
Transformasi, Vol. 12, No. 1, Januari 2016: 92-104

6. Memungkinkan siswa mengembangkan keterampilan dan ketertarikan terhadap kegiatan-kegiatan luar kelas

7. Menumbuhkan pemahaman untuk secara bijak menggunakan dan melindungi lingkungan alam

8. Mengenalkan berbagai kegiatan di luar kelas yang dapat membuat pembelajaran lebih kreatif

9. Memberikan kesempatan yang unik untuk perubahan perilaku melalui penataan latar pada kegiatan luar kelas

10. Memberikan kontribusi untuk membantu mengembangkan hubungan gurumurid yang lebih baik melalui berbagai pengalaman di alam bebas

11. Memberikan kesempatan untuk belajar dari pengalaman langsung melalui implementasi bebas kurikulum sekolah diberbagai area

12. Memanfaatkan sumber-sumber yang berasal dari lingkungan dan komunitas sekitar untuk pendidikan

\section{Manfaat Pembelajaran Luar Kelas (Outdoor Learning)}

Model pembelajaran Outdoor Learning bisa diterapkan pada anak-anak usia Sekolah dan orang dewasa sekaligus. Menurut suyadi menyebutkan, bahwa manfaat pembelajaran luar kelas antara lain: Pikiran lebih jernih, Pembelajaran akan terasa menyenangkan, Pembelajaran lebih variatif, Belajar lebih rekreatif, Belajar lebih riil, Anak lebih mengenal pada dunia nyata dan luas, Tertanam image bahwa dunia sebagai kelas, Wahana belajar akan lebih luar, Kerja otak lebih rileks. $^{76}$

Menurut Sudjana dan Rivai menjelaskan, banyak keuntungan yang dioeroleh dari kegiatan mempelajarai lingkungan dalam proses belajar ${ }^{77}$, antara lain:

1. Kegiatan belajar lebih menarik dan tidak membosankan siswa duduk berjajam, sehingga motivasi belajar siswa akan lebih tinggi.

2. Hakekat belajar akan lebih bermakna sebab siswa dihadapkan dengan situasi dan keadaan yang sebenarnya atau bersifat alami.

\footnotetext{
${ }^{76}$ Ibid.,h. 25

${ }^{77}$ Ibid.,
} 
3. Bahan-bahan yang dapat dipelajari lebih kaya serta lebih factual sehingga kebenarannya akurat.

4. Kegiatan belajar siswa lebih komprehensif dan lebih aktif sebab dapatdilakukan dengan berbagai cara seperti mengamati, bertanya atau wawancara, membuktikan atau mendemonsrrasikan, menguji fakta, dan lain-lain.

5. Sumber belajar lebih kaya sebab lingkungan yang dapat dipelajari bisa beraneka ragam seperti lingkungan social, lingkungan alam, lingkungan buatan, dan lain-lain.

6. Siswa dapat memahami dan menghayati aspek-aspek kehidupan yang ada dilingkungannya, sehingga dapat membentuk pribadi yang tidak asing dengan kehidupan membentuk sekitarnya, serta dapat memupuk cinta lingkungan.

Menurut Direktorat Tenaga Kependidikan proses pembelajaran secara langsung dapat memberikan pengalaman nyata pada sisa, artinya pengalaman itu akan terhindar dari kesalahan persepsi dari pembahasan materi pelajaran tertentu. Sedangkan Menurut Purwanti nilai plus dari outdoor learning ${ }^{78}$ sebagai berikut:

1. Dapat merangsang keinginan siswa untuk mengikuti materi pelajaran guna meningkatkan pengetahuan, sikap, dan ketrampilan siswa terhadap mata pelajaran bahasa Indonesia.

2. Dapat digunakan sebagai media alternatif bagi guru dalam mengembangkan metode mengajar mata pelajaran bahasa Indonesia.

3. Model pembelajaran outdoor learning memberikan alternatif cara pembelajaran dengan membangun makna atau dengan melibatkan lebih banyak indera penglihatan, indera pendengaran, indera perabaan, indera penciuman padasiswa dan memberikan pengalaman yang lebih berkesan, karena siswa mengalami sendiri tentang materi pelajaran.

Di samping Manfaat di atas terdapat juga manpaat yang lain di antaranya; Pikiran siswa lebih segar dan jernih, Pembelajaran akan terasa lebih menyenangkan, Pembelajaran lebih bervariasi, Belajar lebih rekreatif, Belajar lebih nyata, Peserta didik lebih mengenal dunia nyata yang luas, Akan tertanam imaji bahwa dunia

\section{Ibid., 27}


Transformasi, Vol. 12, No. 1, Januari 2016: 92-104

merupakan kelas untuk belajar, Wahana belajar akan lebih luas, Kerja otak akan lebih baik sehingga peserta didik menjadi lebih cerdas

\section{Mata Pelajaran yang Dapat Diajarkan Di Luar Kelas (Outdoor Learning) dan Cara Penerapannya}

Mata Pelajaran yang dapat diajarkan di Luar Kelas dan cara penerapannya antara lain:

1. Bahasa Indonesia (Membaca puisi, Diskusi, Mengarang cerita, Permainan)

2. Ilmu Pengetahuan Alam (Guru mengajak siswa keluar kelas ketempat yang teduh dan menyehatkan untuk kegiatan belajar, Mengajak siswa ke taman atau lingkungan sekitar sekolah dan menyebutkan tumbuhan dikotil dan monokotil Siswa diajak ke kebun binatang

3. Ilmu Pengetahuan Sosial (Siswa diajak jalan-jalan ke pantai asuhan Membuat permainan, Siswa diajak jalan-jalan ke sekitar sekolah)

4. PKN (Materi tolong-menolong, siswa diajak ke PMI Membawa siswa ke halaman kelas lain (berdekatan) kemudian menyetel musik dan berbincangbincang ditempat tersebut, Tentang toleransi di luar kelas, dengan cara mengajak siswa ke tempat ibadah, gereja, masjid, vihara, pura dll.

5. Biologi (Siswa diajak ke kandang sapi Memanfaatkan lingkungan di luar kelas Berkunjung ke kebun binatang)

6. Matematika (Mengajak siswa ke warung dekat sekolah Mengukur tinggi tumbuhan, pohon kecil di halaman depan sekolah Menghitung kecepatan lari di lapangan)

7. Bahasa Inggris (Ajak siswa ke taman, sebutkan bahasa inggris dari masingmasning tanaman tersebut Mengajak siswa ke tempat wisata yang ada orang asingnya).

Dalam rangka penerapan pendekatan pembelajaran di luar kelas beberapa metode dapat digunakan, di antaranya: Metode Penugasan, Metode Tanya jawab, Metode BermainMetode Observasi

Lingkungan Dalam Sekolah (halaman sekolah, taman bunga disekolah, pohon pohon, lapangan, halamnan belakang sekolah, koperasi, dan kolam yg ada 
disekitar sekolah). Lingkungan Luar Sekolah (Persaawahan, kebun binatang, museum, perusahaan, sungai, laut, perkebunan, danau, pegunungan , rumah ibadah, pantai asuhan anak yatim, panti jompo, warung, pasar, pemukiman penduduk, kandang hewan, taman, hutan, cagar alam, objek pariwisata, jembatan).

Terdapat beberapa peran guru yang dapat dilakukan ketika menerapkan pembelajaran di luar kelas, di antaranya: sebagai Fasilitator, Sebagai Teman, Sebagai Pelatih, Sebagai, Motivator.

\section{Kerangka Pemecahan Masalah}

Pemecahan masalah yang ditemukan di lapangan, diilustrasikansebagai berikut:

\section{Observasi}

(di Mts. Babul Mujahidin berkaitan dengan Kualitas guru

\section{Refleksi}

(Bepikir mendalam dengan cara menganalisis masalah-masalah yang paling urgen untuk diselesaikan)

\section{$\checkmark$}

\section{Formulasi Solusi}

(Penulis merencanakan kegiatan pelatihan sebagai solusi permasalahan)

\section{$\checkmark$}

\section{PELATIHAN}

\section{Bagan 1: Kerangka Pemecahan Masalah}

Berdasarkan bagan tersebut dapat dijelaskan bahwa, pada tahap awal penulis melakukan observasi dalam rangka menemukan masalah-masalah yang terjadi di MTs. Babul Mujahidin, selanjutnya pada saat bersamaan saya berdiskusi dengan Kepala Madrasah mengenai masalah yang terjadi brkaitan dengan Kualitas pembelajaran. Tahap selanjutnya adalah refleksi, pada tahap ini saya melakukan analisis terhadap masalah-masalah yang ditemukan di MTs. Babul Mujahidin selanjutnya memilih masalah mana yang paling urgen untuk diselesaikan. Tahap berikutnya adalah merancang/memformulasikan solusi apa yang paling tepat 
untuk mengatasi permasalahan yang terjadi di MTs. Babul Mujahidin, dan selanjutnya dilaksanaknlah Pelatihan dengan tema "Peningkatan Eksistensi Pendidikan di MTs. Babul Mujahidin Desa Bayan Kec. Bayan Kab. Lombok Utara Tahun 2016".

Bentuk pemecahan masalah yang penulis formulasikan adalah berupa memberikan pelatihan dengan tema "Peningkatan Eksistensi Pendidikan di MTs. Babul Mujahidin Desa Bayan Kec. Bayan Kab. Lombok Utara Tahun 2016".

Adapun sasaran kegiatan ini adalah guru-guru semua mata pelajaran yang ada pada MTs. Babul Mujahidin Desa Bayan Kec. Bayan Kab. Lombok Utara. Adapun metode yang digunakan dalam pelatihan ini adalah: Ceramah, Diskusi, Tanya jawab, Praktik

Kegiatan Pelatihan dengan tema "Peningkatan Eksistensi Pendidikan di MTs. Babul Mujahidin Desa Bayan Kec. Bayan Kab. Lombok Utara Tahun 2016". Dilakukan pada tanggal 10 September tahun 2016. Kegiatan pelatihan selanjutnya dilakukan di Aula Kantor Desa Bayan. Selanjutnya kegiatan ini berlangsung satu hari, dengan rincian kegiatan sebagai berikut:

Tabel 1: Jadwal Pelaksanaan kegiatan pengabdian

\begin{tabular}{|c|l|c|c|}
\hline Waktu & \multicolumn{1}{|c|}{ Materi } & $\begin{array}{c}\text { Bentuk } \\
\text { kegiatan }\end{array}$ & \multicolumn{1}{|c|}{ Narasumber } \\
\hline $\mathbf{0 9 . 0 0 - \mathbf { 1 0 . 3 0 }}$ & $\begin{array}{l}\text { Penyampaian Teori } \\
\text { berkaitan Dengan } \\
\text { Pembelajaran Di Luar } \\
\text { kelas (Outdorr } \\
\text { Learning) }\end{array}$ & Ceramah & Ansori, M.Pd \\
\hline $\mathbf{1 0 . 3 0 - \mathbf { 1 2 . 0 0 }}$ & $\begin{array}{l}\text { Diskusi Kelompok } \\
\text { Mata Pelajaran }\end{array}$ & Diskusi & $\begin{array}{l}\text { Nurul Iman, M.Pd } \\
\text { Asrorul Azizi, M.Pd }\end{array}$ \\
\hline & \multicolumn{2}{|c|}{ ISTIRAHAT, SHOLAT, MAKAN } \\
\hline $\mathbf{1 3 . 0 0 - \mathbf { 1 6 . 0 0 }}$ & $\begin{array}{l}\text { Mengembangkan } \\
\text { Perangkat } \\
\text { Pembelajaran } \\
\text { dengan }\end{array}$ & Praktik & $\begin{array}{l}\text { Ansori, M.Pd } \\
\text { Nurul Iman, M.Pd } \\
\text { Asrorul Azizi, } \\
\text { M.Pd }\end{array}$ \\
\hline
\end{tabular}


Adapun pihak-pihak yang dilibatkan pada kegiatan Pelatihan dengan tema "Peningkatan Eksistensi Pendidikan di MTs. Babul Mujahidin Desa Bayan Kec. Bayan Kab. Lombok Utara Tahun 2016" ini adalah:

1. Guru-guru Mata Pelajaran di MTs. Babul Mujahidin Desa Bayan

2. Narasumber selain penulis

3. Mahasiswa/I yang sedang melaksanakan program KKP di Desa Bayan Kendala-kendala yang dihadapi berupa:

1. Waktu pelaksanaan sehari penuh sehingga membuat peserta menjadi jenuh

2. Peserta terlalu banyak sementara ruangan tidak cukup besar.

3. Daya tangkap masing-masing peserta berbeda, hal ini mengakibatkan waktu yang dibutuhkan semakin banyak. Solusinya adalah penulis bersama tutor harus lebih bersabar memberikan bimbingan secara personal kepada peserta.

Penilaian keberhasilan pelaksanan Pelatihan dengan tema "Peningkatan Eksistensi Pendidikan di MTs. Babul Mujahidin Desa Bayan Kec. Bayan Kab. Lombok Utara Tahun 2016" dilakukan dengan cara melakukan pendampingan (Penulis beserta narasumber) datang ke Mts. Babul Mujahidin. Pendampingan ini penulis lakukan selama satu bulan lebih, terhitung setelah berlangsungnya kegiatan pelatihan di Aula Kantor Desa Bayan, dan hasilnya adalah peserta pelatihan terutama guru terlihat sudah mulai mencoba menggunakan pendekatan pembelajaran di luar kelas (outdoor learning).

\section{PENUTUP}

Terkait dengan pelaksanan Pelatihan dengan tema "Peningkatan Eksistensi Pendidikan di MTs. Babul Mujahidin Desa Bayan Kec. Bayan Kab. Lombok Utara Tahun 2016" ini, beberapa hal dapat disimpulkan, di antaranya:

1. Dengan adanya Pelatihan dengan tema "Peningkatan Eksistensi Pendidikan di MTs. Babul Mujahidin Desa Bayan Kec. Bayan Kab. Lombok Utara Tahun 2016", peserta pelatihan dapat memahami bagaimana penerapan pendekatan pembelajaran di luar kelas.

2. Dengan adanya Pelatihan dengan tema "Peningkatan Eksistensi Pendidikan di MTs. Babul Mujahidin Desa Bayan Kec. Bayan Kab. Lombok Utara Tahun 2016", peserta pelatihan dapat menerapkan pendekatan pembelajaran di luar 
Transformasi, Vol. 12, No. 1, Januari 2016: 92-104

kelas, hal ini tercermin dari perangkat pembelajaran yang sudah dikembangkan oleh guru..

Terkait dengan telah berlangsungnya Pelatihan dengan tema "Peningkatan Eksistensi Pendidikan di MTs. Babul Mujahidin Desa Bayan Kec. Bayan Kab. Lombok Utara", penulis menyarankan beberapa hal, di antaranya:

1. Sebaiknya sebelum melaksanakan pelatihan, guru-guru terlebih dahulu dihimbanu untuk menyiapkan segala hal terkait dengan kesiapan mereka mengikuti pelatihan.

2. Daya tangkap guru menjadi hal yang sangat penting untuk diperhatikan oleh pelatih/tutor berikutnya, mengingat daya tangkap masing-masing guru berbeda.

\section{DAFTAR PUSTAKA}

vera, Adelia, Metode Mengajar Anak di Luar Kelas (Outdoor Study). Yogyakarta: DIVA Press, 2012.

Suherman, Ayi, Pengembangan Outdoor Education Pendidikan Jasmani Berbasis Kompetensi di Sekolah Dasar. Skripsi. Yogyakarta: Universitas Negeri Yogyakarta, 2011.

Husamah, Pembelajaran Luar Kelas Outdoor Learning, Jakarta: Prestasi Pustakaraya, 2013. 